\title{
Changing expression of chloride channels during preimplantation mouse development
}

\author{
I Arnaiz ${ }^{1}, \mathrm{M} \mathrm{H}$ Johnson ${ }^{1,2}, \mathrm{D}$ I Cook $^{1}$ and M L Day ${ }^{1}$ \\ ${ }^{1}$ School of Medical Sciences, Discipline of Physiology and Bosch Institute, University of Sydney, Sydney, New South \\ Wales 2006, Australia and ${ }^{2}$ Department of Physiology, Development and Neuroscience, and Centre for Trophoblast \\ Research, University of Cambridge, Downing Street, Cambridge CB2 3DY, UK
}

Correspondence should be addressed to M L Day; Email: margotd@physiol.usyd.edu.au

\begin{abstract}
Plasma membrane chloride channels (CICs) play important roles in a broad range of cellular processes including cell volume regulation, proliferation, and transepithelial transport, all of which are critical during preimplantation embryonic development. In this study, the molecular and functional expression of voltage-gated CICs was analyzed throughout preimplantation development of the mouse conceptus. mRNA transcripts for all Clcn genes were detected. Only Clcn1 mRNA showed differential expression in the blastocyst, being detected in the trophectoderm but not in the inner cell mass. CLCN3 protein was detected at low levels in the cytoplasm and plasma membrane in 4-cell embryos and was localized to the apical plasma membrane of the trophoblasts in the blastocyst. Whole-cell patchclamp recordings demonstrated the presence of a DIDS-sensitive, outwardly rectifying $\mathrm{Cl}^{-}$current throughout development, with this conductance being large at the 1-cell, morula and blastocyst stages. A second DIDS-insensitive $\mathrm{Cl}^{-}$current, which was inactivated by membrane depolarization, was present in cells differentiating into the trophoblast lineage and during blastocyst expansion. Inhibition of the DIDS-sensitive current and the DIDS-insensitive current, with 9-AC, prevented blastocyst expansion.
\end{abstract}

Reproduction (2013) 145 73-84

\section{Introduction}

The ionic environment experienced by the conceptus is likely to exert a powerful effect on its development. The extent of this effect will depend on the ability of the conceptus to regulate its ionic composition in response to external ionic change, which will ultimately depend on the activity of ion channels and the ions transported at each developmental stage. Our knowledge of the ion transporters and channels functioning at early stages of development is limited and this deficit may hinder attempts to improve embryo culture media used in human-assisted reproductive technologies (Biggers 2002, Leese et al. 2007). A fairly detailed analysis of the mechanisms available to the conceptus for the handling of acid and alkaline load, including $\mathrm{Na}^{+}-\mathrm{H}^{+}$ exchangers, $\mathrm{H}^{+}$-monocarboxylate cotransporters, and $\mathrm{Cl}^{-}-\mathrm{HCO}_{3}^{-}$exchangers, has been described (Gibb et al. 1997, Harding et al. 1999). However, for ions other than $\mathrm{H}^{+}$, information is less systematic. It is clear that $\mathrm{Ca}^{2+}$ plays critical roles at various stages of preimplantation development, including fertilization (McGuinness et al. 1996, Day et al. 2000), and during signaling by embryotrophic factors during later stages ( $\mathrm{Li}$ et al. 2007, O'Neill 2008). There is also evidence implicating monovalent cations $\left(\mathrm{Na}^{+}\right.$and $\left.\mathrm{K}^{+}\right)$in the temporal
(Day et al. 1993, 1998) and spatial (Wiley 1984, Wiley et al. 1990, 1991) programing of early development.

Channels that selectively allow passage of $\mathrm{Cl}^{-}$ions across membranes are thought to play a number of roles in the physiology of somatic cells, and so an understanding of which channels are present and active during the preimplantation stages of development is likely to be important. Molecular studies have identified several genes expressing proteins with $\mathrm{Cl}^{-}$transport characteristics. In parallel, electrophysiological studies have identified $\mathrm{Cl}^{-}$channels and transporters with distinctive physiological characteristics and with involvement in a number of physiological activities, including volume regulation in response to osmotic stress (Strange et al. 1996), $\mathrm{pH}$ regulation in response to alkaline load, and passage through the cell cycle (Block \& Moody 1990, Rutledge et al. 2001). We currently have only very limited information about patterns of chloride channel (CIC) gene expression and activity during preimplantation development. There is evidence for the activity of an osmo-sensitive $\mathrm{ClC}$, which also transports organic osmolytes, and is active during the latter stages of oocyte maturation and the first two cell cycles of mouse development, declining at entry into second mitotic metaphase (Séguin \& Baltz 1997, Kolajova \& Baltz 1999, Kolajova et al. 2001). In addition, there are several 
reports of the presence of a $\mathrm{Cl}^{-}-\mathrm{HCO}_{3}^{-}$exchanger in conceptuses from several species, which plays a role in the alkaline load response of the early conceptus (Lane et al. 1999a, 1999b, Phillips \& Baltz 1999, Harding et al. 2002).

Here, we report on the profile of mRNA expression of the genes encoding the major voltage-gated $\mathrm{ClCs}$ and an electrophysiological study of $\mathrm{ClC}$ activity during preimplantation mouse development. We find that at least two ClCs are detectable electrophysiologically and that the profile of the activities varies with developmental stage and emergent tissue lineages. In addition, we find that mRNAs encoding eight $\mathrm{ClCs}$ are detectable.

\section{Results}

\section{Expression of Clcn mRNA in mouse oocytes and conceptuses}

RT-PCR were carried out on RNA from all stages of development from the unfertilized oocyte through to the blastocyst stage. Transcripts for all the Clcn genes were detected (Fig. 1, Table 1). Clcn1, 2, 3, 4, 5, 6, 7, and ka/b mRNAs were detected in all stages of development examined, although expression levels of $\mathrm{Clcn} 2$ and 5 appeared to dip during the 2-cell stage and those of Clcnka/b (Clcnk1/2) was weak before fertilization (Table 1, Figs 1 and 2). A more detailed examination of the expression of Clcn3 mRNA showed that it was present in oocytes, 1 -cell and early 2 -cell stages, absent from mid 2-cell to late 2-cell stages, and present from the

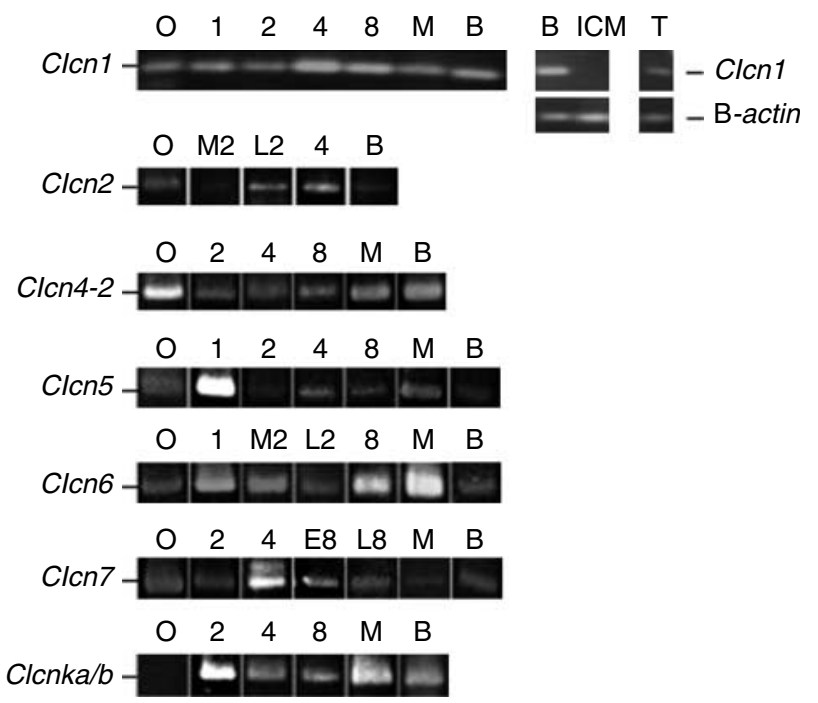

Figure 1 Expression of mRNA encoding Clcn1, Clcn2, Clcn4-2 (Clcn4), Clcn5, Clcn6, Clcn7, and Clcnka/b in the preimplantation mouse embryo. Representative PCR products from unfertilized oocytes $(\mathrm{O})$, 1-cell (1), 2-cell (2), 4-cell (4), 8-cell (8), morula (M), and blastocyst (B) stage embryos are shown. ICM and TE indicates inner cell mass and trophectoderm respectively. $E, M$, and $L$ indicate early, mid, and late stages respectively. Each reaction was repeated on two to eight separate cDNA samples. early 4-cell stage through to the blastocyst stage (Fig. 2A). Within the blastocyst, Clcn3 mRNA was found in both inner cell mass (ICM) and trophectoderm (TE) cells (Fig. 2B). Clcn1 mRNA was only detected in cells from the trophoblast of blastocysts but not in the ICM (Fig. 1).

\section{Immunolocalization of CLCN3}

Expression of $\mathrm{CLCN} 3$ protein, the product of the Clcn3 gene, in mouse preimplantation stages was investigated by immunofluorescence, this being the only channel protein for which validated antibodies are available. In 4-cell embryos, weak staining for CLCN3 was distributed throughout the cytoplasm and membrane (Fig. 2C, panel a). In the blastocyst stage, there was strong staining of the apical membrane of the trophoblasts (Fig. 2C, panel d). There was also diffuse staining throughout the cytoplasm of both ICM and trophoblasts. When the antibody was preadsorbed with the peptide antigen (Fig. 2C, panels b and e) or when the secondary antibody only was used (Fig. 2C, panels c and f), very little staining was observed.

\section{$\mathrm{Cl}^{-}$currents in preimplantation embryogenic cells}

Whole-cell patch-clamp studies on 1-cell stage mouse zygotes under isotonic conditions using a $\mathrm{Cl}^{-}$-rich bath solution identified an outwardly rectifying current $(n=6$; Fig. 3). Following replacement of extracellular $\mathrm{Cl}^{-}$with glutamate $\left(\mathrm{Cl}^{-}\right.$free bath solution), the size of this conductance was reduced significantly (Fig. 3A, B and C) and the reversal potential shifted from $-16.4 \pm 2.6 \mathrm{mV}$ $(n=6)$ to $8.7 \pm 4.1 \mathrm{mV}(n=6 ; P<0.001)$. Addition of $100 \mu \mathrm{M}$ 4,4'-diisothiocyanostilbene-2,2'-disulfonate (DIDS), a broad specificity inhibitor of $\mathrm{Cl}^{-}$channels, in the presence of the $\mathrm{Cl}^{-}$containing extracellular solution also significantly decreased the size of the outward current ( $n=5$; Fig. 3D), as expected if the current was due to movement of $\mathrm{Cl}^{-}$through a channel.

The expression of this DIDS-sensitive outwardly rectifying $\mathrm{Cl}^{-}$conductance in later stages of preimplantation development was also investigated. At the 4-, 8-cell, and morula stages, an outward conductance with properties similar to that observed in the zygote was present in whole-cell recordings. This current was reduced significantly by removal of extracellular $\mathrm{Cl}^{-}$(Fig. 4). Addition of $100 \mu \mathrm{M}$ DIDS significantly reduced the conductance in 4-cell stage embryos and morulae (Fig. 4A and C) but had no significant effect on the conductance at the 8-cell stage (Fig. 4B).

In the mouse blastocyst, an outwardly rectifying $\mathrm{Cl}^{-}$current was also observed in isolated ICMs and in the trophoblast of expanded, day 5 embryos (Fig. 5). Addition of DIDS $(100 \mu \mathrm{M})$ to the bathing solution significantly reduced the current in both these cell types (Fig. 5A and B(iii)). 
Table 1 Voltage-gated $\mathrm{Cl}^{-}$channel transcript expression in the preimplantation mouse embryo.

\begin{tabular}{|c|c|c|c|c|c|c|c|}
\hline Chloride channel & UF & 1-Cell & 2-Cell & 4-Cell & 8-Cell & Mor & BL \\
\hline Clcn1 & + & + & + & + & + & + & + \\
\hline Clcn2 & + & ND & + & + & ND & ND & + \\
\hline Clcn3 & + & + & + & + & + & + & + \\
\hline Clcn4-2 & + & ND & + & + & + & + & + \\
\hline Clcn5 & + & + & + & + & + & + & + \\
\hline Clcn6 & + & + & + & ND & + & + & + \\
\hline Clcn7 & + & + & + & + & + & + & + \\
\hline Clcnka/b & ND & ND & + & + & + & + & + \\
\hline
\end{tabular}

ND, RT-PCR not done; +, band present; - , band absent. RNA from unfertilized oocytes (UF); 1-, 2-, 4-, and 8-cell, morula (mor), and blastocyst (BL) stages were used. Each reaction was repeated three to 16 times.

\section{Comparison of the $\mathrm{Cl}^{-}$- and DIDS-sensitive components of the outwardly rectifying conductance throughout development}

The sensitivity of different voltage-gated $\mathrm{Cl}^{-}$channels to inhibition by DIDS varies. Therefore, to determine whether all the $\mathrm{Cl}^{-}$conductance measured at each embryogenic stage of development was blocked by DIDS, the size of the $\mathrm{Cl}^{-}$-sensitive conductance was compared with the size of the conductance that was blocked by DIDS. The $\mathrm{Cl}^{-}$-sensitive conductance was calculated from the change in conductance before and after removal of extracellular $\mathrm{Cl}^{-}$. Similarly, the DIDS-sensitive conductance was calculated from the change in conductance before and after the addition of $100 \mu \mathrm{M}$ DIDS, in the presence of extracellular $\mathrm{Cl}^{-}$. The size of the $\mathrm{Cl}^{-}$-sensitive conductance was significantly smaller at the 4- and 8-cell stages compared with that measured in the zygote. It increased again at the morula stage before decreasing in the ICM and trophoblast of the blastocyst (Fig. 6). The sizes of the $\mathrm{Cl}^{-}$-sensitive and DIDS-sensitive conductances were the same for all stages except for the morula and trophoblast of expanded blastocysts, in which the size of the DIDS-sensitive conductance was smaller than the total $\mathrm{Cl}^{-}$-sensitive conductance. Following blastocyst collapse, this difference between the conductances in trophoblasts was abolished. These data suggest that more than one type of $\mathrm{Cl}^{-}$channel was expressed in morulae and trophoblasts, one channel that was inhibited by DIDS and another that was not inhibited by DIDS.

\section{Voltage-inactivated $\mathrm{Cl}^{-}$currents in preimplantation stages}

A second type of $\mathrm{Cl}^{-}$current, which showed voltagesensitive, slow inactivation at higher positive voltages

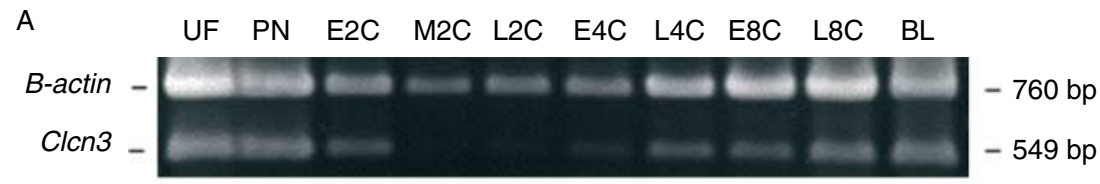

B

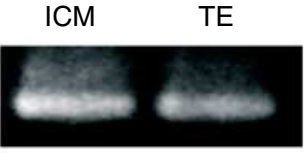

$-549 \mathrm{bp}$

C
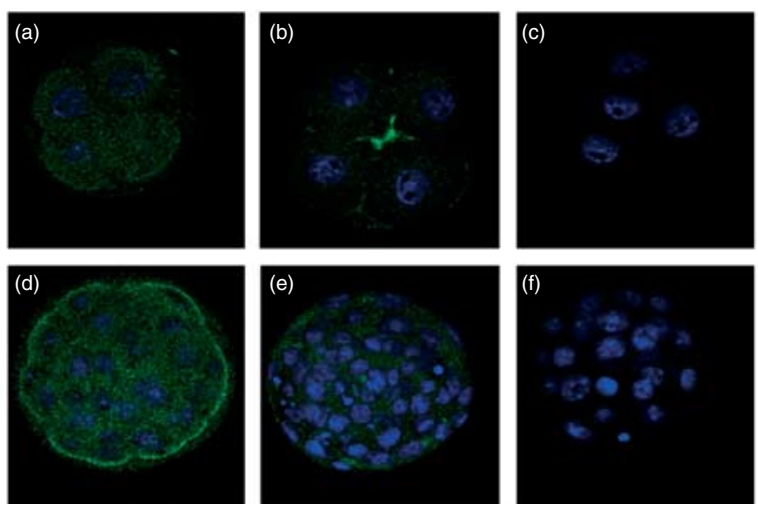

Figure 2 Expression of $\mathrm{Cl} c \mathrm{cn} 3 \mathrm{mRNA}$ and protein in mouse preimplantation embryos. (A) Representative RT-PCR products from amplification of $\mathrm{Cl}_{\mathrm{cn} 3}$ and $B$-actin in unfertilized oocytes (UF), 1-cell (1C), early 2-cell (E2C), mid 2-cell (M2C), late 2-cell (L2C), early 4-cell (E4C), late 4-cell (L4C), early 8-cell (E8C), late 8-cell (L8C), and blastocyst (BL) stage embryos. (B) Representative RT-PCR products from amplification of $\mathrm{Cl}_{\mathrm{cn} 3}$ in inner cell mass (ICM) and mural trophectoderm (TE) cells of blastocyst stage embryos. Each reaction was repeated two to eight times. Sizes of PCR products are indicated. (C) Distribution of CLCN3 in the 4-cell ( $a, b$ and $c$ ) and blastocyst ( $d$, e and f) stages stained with anti-CLCN3 antibody (a and d), anti-CLCN3 preadsorbed with the peptide antigen (b and e), and secondary antibody only (c and f). Green indicates antibody staining and blue indicates DAPI staining of the nuclei. Each image is representative of staining observed in three separate experiments.

\section{+
+
+
+
+
+
+
+}

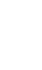


A (i) $\mathrm{Cl}^{-}$-rich bath solution

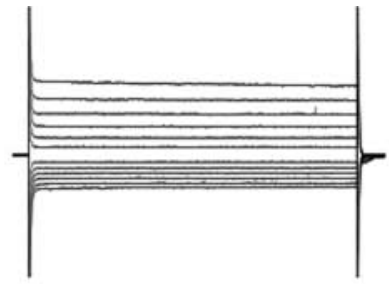

(ii) $\mathrm{Cl}^{-}$-bath solution

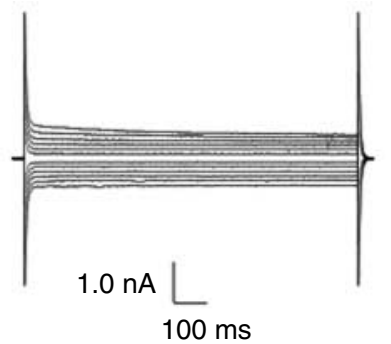

B

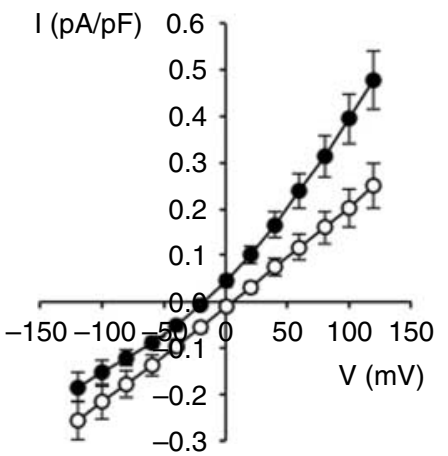

C

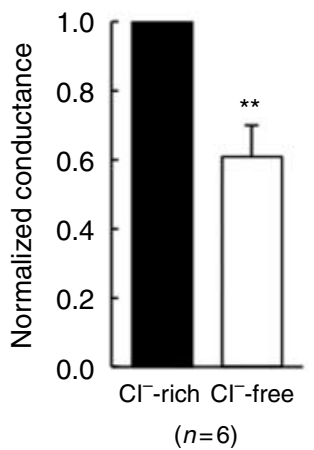

D

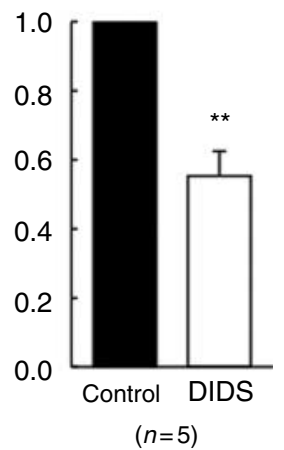

Figure 3 Characteristics of the outwardly rectifying $\mathrm{Cl}^{-}$current in 1-cell stage embryos. (A) Representative current tracings obtained using (i) $\mathrm{Cl}^{-}$-rich and (ii) $\mathrm{Cl}^{-}$-free (Na-glutamate) bath solutions. (B) Mean current-voltage (I-V) relationship for the steady-state current recorded in the $\mathrm{Cl}^{-}$-rich (filled circle) and $\mathrm{Cl}^{-}$-free (open circle) bath solutions from six embryos. Normalized chord conductance of the outwardly rectifying $\mathrm{Cl}^{-}$current in 1-cell stage embryos measured at $100 \mathrm{mV}(\mathrm{C})$ in $\mathrm{Cl}^{-}$-rich and $\mathrm{Cl}^{-}$-free bath solutions and (D) in the presence of $100 \mu \mathrm{M}$ DIDS. Conductance was normalized to $\mathrm{Cl}^{-}$-rich or control values. Data are shown as mean \pm s.E.M. with $(n)$ the number of recordings. ${ }^{* *} P<0.01$. was also observed in preimplantation stages (Fig. 7). DIDS $(100 \mu \mathrm{M})$ did not inhibit this voltage-inactivated current in day 4 blastocysts, although the total outward $\mathrm{Cl}^{-}$conductance was reduced (Fig. 7B), consistent with DIDS having an inhibitory effect on the underlying outwardly rectifying $\mathrm{Cl}^{-}$current described in the previous sections. The voltage-inactivated current was observed in morula and blastocyst stages, but rarely if ever at earlier cleavage stages or in the ICM (Fig. 7C). Moreover, when isolated embryogenic cells were examined (Fig. 7D), this voltage-inactivated current was absent in apolar $1 / 16$ cells $(n=5)$, observed in $6 \%$ of polar $1 / 16$ cells $(n=16), 38 \%$ of polar $1 / 32$ cells $(n=21)$, and $57 \%$ of $1 / 64$ trophoblast cells $(n=28)$. This current was absent from ICM cells $(n=5)$ but observed in a significantly greater proportion of trophoblasts in collapsed than in expanded blastocysts (Fig. 7E).

\section{Effect of $\mathrm{Cl}^{-}$channel inhibitors on blastocoel cavity formation}

Previous studies have shown that $\mathrm{Cl}^{-}$transport plays an important role in blastocyst expansion. In order to determine whether the $\mathrm{Cl}^{-}$-sensitive conductances observed in this study played a role in blastocyst expansion, the effect of $\mathrm{Cl}^{-}$channel blockers on blastocoel cavity formation was investigated. Culture of morulae in medium containing $100 \mu \mathrm{M}$ DIDS significantly reduced the proportion of embryos that formed a fluid-filled cavity (Fig. 8). As Clcn1 mRNA showed a similar pattern of expression to the voltage-inactivated
$\mathrm{Cl}^{-}$current observed in the trophoblast lineage, we investigated whether the $\mathrm{ClC} 1$ channel blocker 9-anthracenecarboxylic acid (9-AC) had any effect on cavity formation. Morulae exposed to $1 \mathrm{mM}$ 9-AC showed a significantly reduced rate of cavitation compared with control morulae, which formed expanded blastocysts (Fig. 8). As we hypothesized that DIDS and 9-AC were blocking different $\mathrm{Cl}^{-}$channels, we also examined the effect of the drugs in combination. Culture of morulae in medium containing $100 \mu \mathrm{M}$ DIDS $+1 \mathrm{mM}$ 9-AC reduced cavity formation to a greater extent than either drug alone.

\section{Discussion}

There is considerable evidence that even quite short periods of in vitro culture can induce a number of changes in the conceptus, which can affect developmental potential and even survival (reviewed in Thompson et al. (2007)). Understanding how the composition of the culture medium influences development thus has potentially important practical consequences. Ions are known to exert important influences through their effects on cell physiology (Leese 1995, Biggers 1998), so understanding the nature and properties of the ion transport systems available to the conceptus is of particular significance.

This study investigated the expression of members of the voltage-gated $\mathrm{Cl}^{-}$channel family during mouse preimplantation development. mRNAs encoding all the Clcn channels were detected throughout development 
A

(i) 4-Cell stage

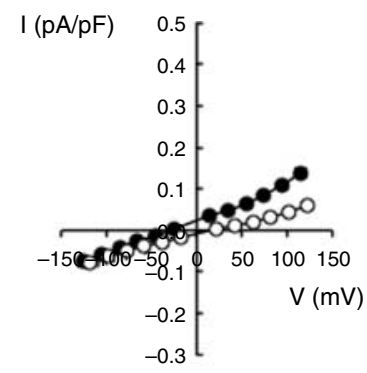

B

(i) 8-Cell stage

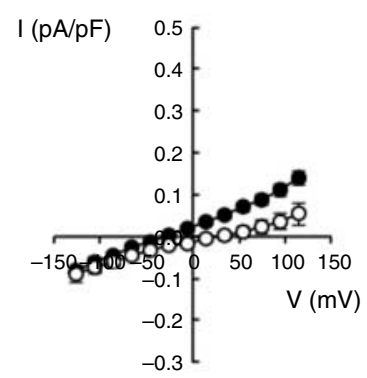

C

(i) Morula

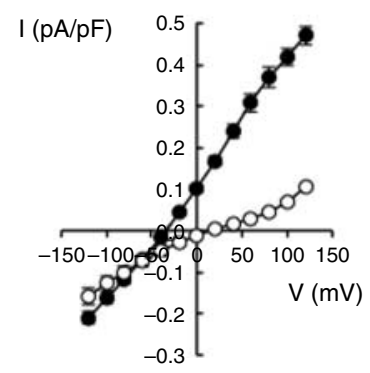

(ii)

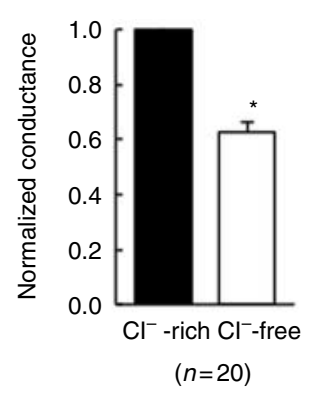

(ii)

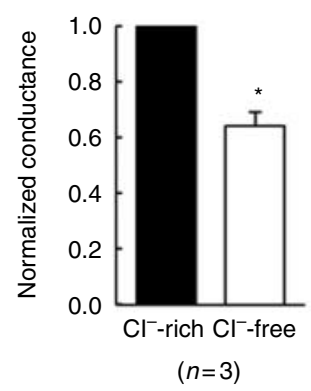

(ii)

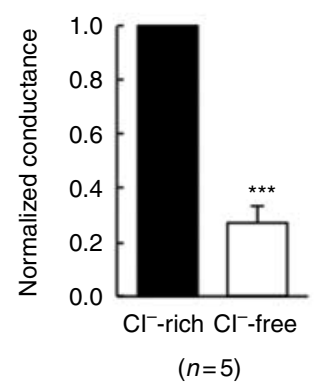

(iii)

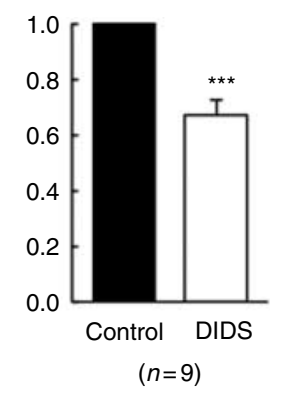

(iii)

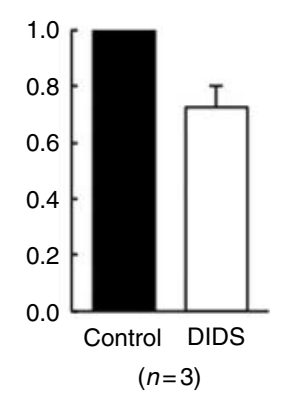

(iii)

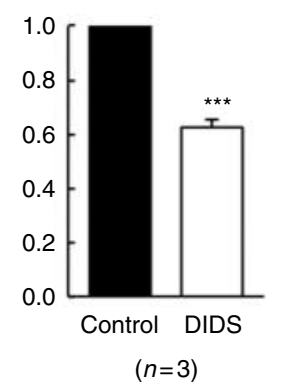

Figure 4 The outwardly rectifying $\mathrm{Cl}^{-}$current in 4-, 8-cell, and morula stage embryos. (i) Mean I-V relationship for the steady-state current recorded in 4-cell (A), 8-cell (B), and morula (C) stages in isotonic $\mathrm{Cl}^{-}$-rich (filled circle) and $\mathrm{Cl}^{-}$-free (open circle) bath solutions. Normalized chord conductance of the outward $\mathrm{Cl}^{-}$current (ii) in the presence and in the absence of extracellular $\mathrm{Cl}^{-}$and (iii) in the presence of $100 \mu \mathrm{M}$ DIDS. Data are shown as mean \pm s.E.M. with $(n)$ the number of recordings. ${ }^{*} P<0.05$ and ${ }^{* * *} P<0.001$. extending a previous report of $\mathrm{Cl} c$ n expression in zygotes (Sonoda et al. 2003). Two types of ClC activities were detected using whole-cell voltage clamp methods. Both these currents had reversal potentials consistent with chloride being the main permeable ion, the removal of extracellular chloride reducing the size of the outward current, and causing a positive shift in the reversal potential as expected for a $\mathrm{Cl}^{-}$conductance. One of these $\mathrm{Cl}^{-}$currents was outwardly rectifying and was inhibited by DIDS. This current was constitutively active throughout the preimplantation stages of embryonic development, being large in the 1-cell and morula stages. In the 1-, 4-, and 8-cell stages, the DIDS-sensitive current constituted all the $\mathrm{Cl}^{-}$-sensitive current. The electrophysiological characteristics of this outwardly rectifying $\mathrm{Cl}^{-}$current were similar to that of a current described previously in the preimplantation mouse embryo under both isotonic and hypotonic conditions (Kolajova \& Baltz 1999, Kolajova et al. 2001, Sonoda et al. 2003). In the blastocyst, this DIDS-sensitive current was present in both the TE and the ICM. When blastocysts were collapsed by disruption of the tight junctions with cytochalasin $D$, the inhibition of the outwardly rectifying $\mathrm{Cl}^{-}$current by DIDS was increased. This suggests that either the $\mathrm{Cl}^{-}$channel was only active during the process of expansion or that the channel was located on the basolateral surface and that DIDS could not access the interior of the trophoblast cells due to the presence of tight junctions between the cells. DIDS reduced cavity formation supporting a role for this conductance in the process of blastocyst expansion.

The second type of $\mathrm{Cl}^{-}$conductance observed in embryos was inactivated at voltages $>+60 \mathrm{mV}$ and was not inhibited by DIDS. This conductance was detected predominantly from the morula stage of development. Compaction of embryonic blastomeres at the 8-cell stage in mice results in the formation of two separate cell types, the ICM and the TE. The appearance of the 
A

Inner cell mass

(i)

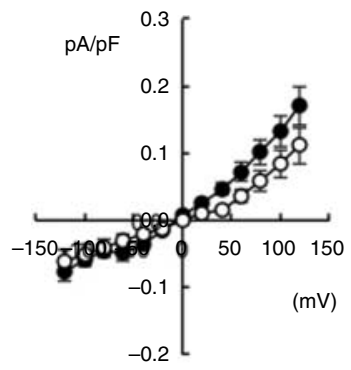

B Trophoblast

(i)

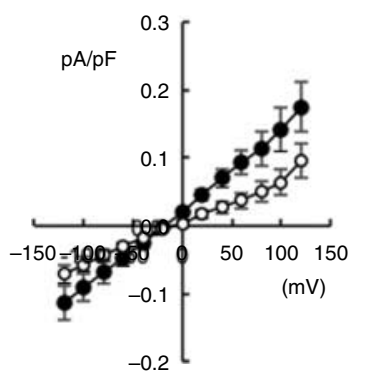

(ii)

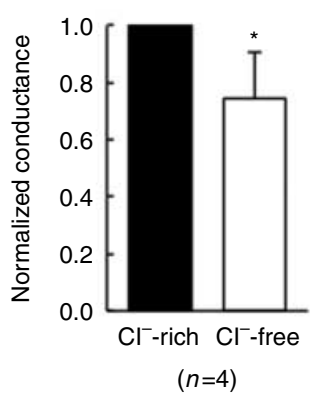

(ii)

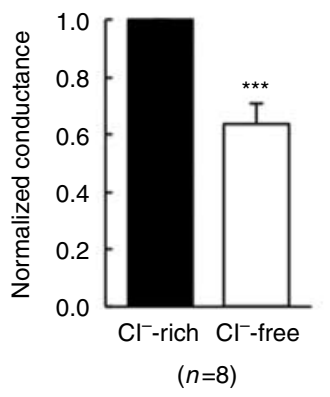

(iii)

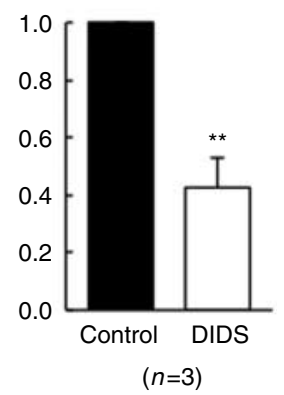

(iii)

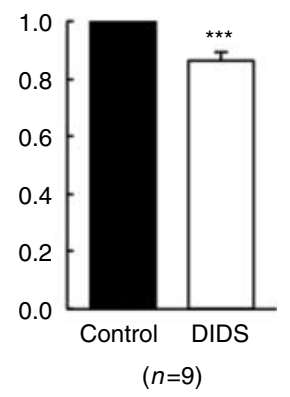

Figure 5 The outwardly rectifying $\mathrm{Cl}^{-}$current in the inner cell mass and trophoblast of the blastocyst. (i) Mean I-V relationship for the steady-state current recorded in inner cell mass $(\mathrm{A})$ and trophoblast $(\mathrm{B})$ in isotonic $\mathrm{Cl}^{-}$-rich (filled circle) and $\mathrm{Cl}^{-}$-free (open circle) bath solutions. Normalized chord conductance of the outward $\mathrm{Cl}^{-}$current in (ii) the presence and absence of extracellular $\mathrm{Cl}^{-}$and (iii) in the presence of $100 \mu \mathrm{M}$ DIDS. Data are shown as mean \pm S.E.M. with $(n)$ the number of recordings. $* P<0.05, * * P<0.01$, and ${ }^{* * *} P<0.001$. voltage-inactivated $\mathrm{Cl}^{-}$conductance was associated with the emergence of this trophoblast lineage (Johnson 1986, 2009), suggesting a role for this conductance in the vectorial movement of electrolytes and water into the blastocoel cavity. Expansion of the blastocoel cavity in the mouse blastocyst requires extracellular $\mathrm{Cl}^{-}$, is dependent on both paracellular and transcellular movement of $\mathrm{Cl}^{-}$across the TE (Manejwala et al. 1989, Brison \& Leese 1993, Zhao et al. 1997), and is driven by the basolaterally localized $\mathrm{Na}^{+}-\mathrm{K}^{+}$-ATPase (DiZio \& Tasca 1977, Biggers et al. 1978, Watson \& Kidder 1988). In this study, DIDS did not completely prevent blastocyst expansion, as observed previously (Zhao et al. 1997), an observation that suggested a role for other pathways for $\mathrm{Cl}^{-}$movement such as the paracellular pathway or the DIDS-insensitive, voltage-inactivated current described here. In the rat, DIDS reduces the rate of blastocyst re-expansion after collapse (Brison \& Leese 1993), and in this study on mouse blastocysts, DIDS was only able to completely block $\mathrm{Cl}^{-}$conductance when blastocysts were collapsed, supporting the possibility that a basolaterally located $\mathrm{Cl}^{-}$channel is important for expansion.

The voltage-gated $\mathrm{Cl}^{-}$channel gene family encodes $\mathrm{Cl}^{-}$channels and $\mathrm{Cl}^{-} / \mathrm{H}^{+}$exchangers that are expressed in the plasma membrane and intracellular vesicles (for review, see Jentsch (2008)). Members of this family that are localized to the plasma membrane include $\mathrm{ClC} 1,2,3, \mathrm{k} 1$, and $\mathrm{k} 2$, all of which were detected at the RNA level in embryos. Of these, ClC2, $3, \mathrm{~K} 1$, and $\mathrm{K} 2$ are inhibited by DIDS; however, only CLCN3 is outwardly rectifying. The current elicited by CLCN3 under isotonic conditions in other cell types (Guan et al. 2006, Mitchell et al. 2008, Cuddapah \& Sontheimer 2010, Yang et al. 2011) has properties similar to the DIDS-sensitive current we have found throughout

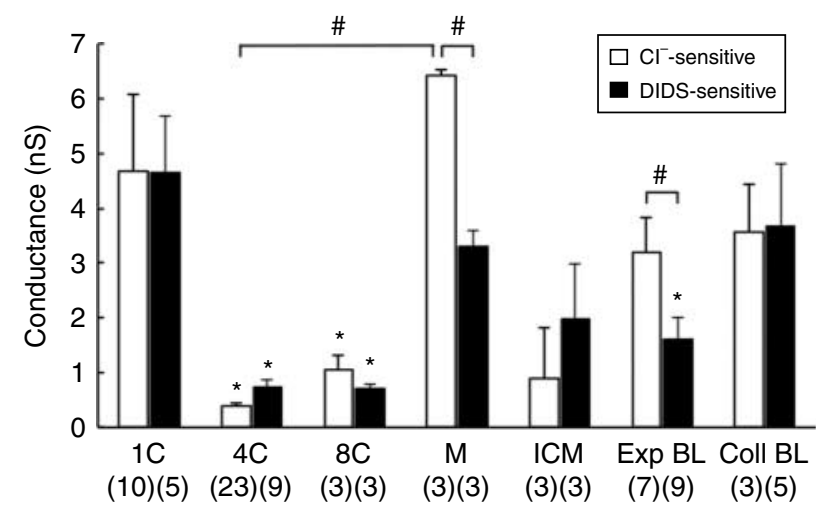

Figure 6 Plots of the conductance of the $\mathrm{Cl}^{-}$- (white bars) and DIDS-sensitive (black bars) currents during preimplantation development and in trophoblasts of expanded (exp BL) and collapsed (coll BL) blastocysts. Data are shown as mean \pm S.E.M. with $(n)$ the number of recordings. *Significant difference $(P<0.05)$ from the conductance at the 1 -cell stage. ${ }^{\#}$ Significant difference $(P<0.05)$ between the $\mathrm{Cl}^{-}$- and DIDS-sensitive currents at a particular stage. 
A

C

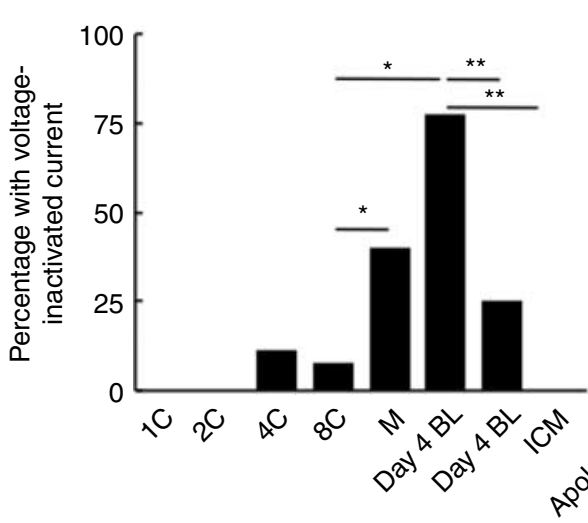

B

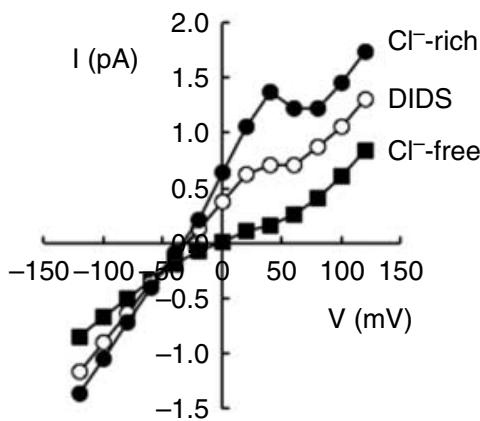

Figure 7 Expression of a voltage-inactivated $\mathrm{Cl}^{-}$current in mouse preimplantation stages of development. (A) Representative current tracings obtained from a trophoblast cell in an expanded blastocyst. (B) Representative I-V relationships obtained in isotonic $\mathrm{Cl}^{-}$-rich (filled circle) and $\mathrm{Cl}^{-}$-free (filled square) bath solutions and in the presence of $100 \mu \mathrm{M}$ DIDS (open circle). (C) Incidence of the voltage-inactivated current throughout development in 1-cell $(1 C ; n=15)$, 2-cell (2C; $n=5)$, 4-cell (4C; $n=26), 8$-cell (8C; $n=13)$, morula $(M ; n=5)$ stages, expanding blastocysts (day $4 \mathrm{BL} ; n=22$ ), expanded blastocysts (day $5 \mathrm{BL} ; n=12)$, and inner cell mass (ICM; $n=5)$; (D) in isolated single cells and small clusters of apolar $1 / 16$ cells $(n=5)$ and polar $1 / 16(n=16), 1 / 32$ $(n=21)$ and $1 / 64(n=28)$ cells; and in (E) trophoblasts of collapsed $(n=5)$ and expanded $(n=12)$ blastocysts. ${ }^{*} P<0.05,{ }^{*} P<0.01$, and ${ }^{* * *} P<0.001$.

preimplantation embryo development. Furthermore, mRNA encoding $\mathrm{Cl}_{\mathrm{cn} 3} \mathrm{\text {was }}$ detected throughout development and CLCN3 protein was present in the plasma membrane at the 4-cell stage and localized to the apical membrane of trophoblasts. $\mathrm{CLCN} 3$ is also a candidate for the volume-sensitive outwardly rectifying anion channel (VSOAC) seen in many cell types (Duan et al. 1997, Yamamoto-Mizuma et al. 2004) as well as mouse embryos (Kolajova \& Baltz 1999, Kolajova et al. 2001). However, the molecular identity of VSOAC has not been firmly established to be CLCN3. There is also evidence in other cell types for the involvement of CLCN3 in $\mathrm{Cl}^{-}$currents observed under isotonic conditions (Yang et al. 2011) and for these currents being required for cell proliferation (Habela et al. 2008, Tang et al. 2008, Zhu et al. 2012). In mouse embryos, VSOAC is only present in the oocyte, 1-, and 2-cell stages in which its activation by hypotonicity is cell cycle dependent (Kolajova \& Baltz 1999, Kolajova et al. 2001). DIDS prevents cell proliferation and development of mouse embryos (Sonoda et al. 2003, Li et al. 2009), suggesting that $\mathrm{CLCN} 3$ may play a role in regulation of the resting cell volume, and thereby cell proliferation, throughout development.

The molecular identity of the voltage-inactivated $\mathrm{Cl}^{-}$current remains unclear. This current is unlikely to be carried by $\mathrm{ClC} 2$, which produces currents that are activated by membrane hyperpolarization and show inward rectification (Thiemann et al. 1992), or by ClCKa/ $\mathrm{b}$ as these channels are inhibited by DIDS (Picollo et al.
2004). On the other hand, Clcn1 mRNA showed a similar expression pattern to the voltage-inactivated $\mathrm{Cl}^{-}$current in embryos, being only expressed in the trophoblast and not the ICM. There is no report of voltage inactivation of currents elicited by $\mathrm{ClC} 1$ in other cell types, although there is evidence that $\mathrm{ClC} 1$ forms heteromultimers with other $\mathrm{ClC}$ subtypes and this alters the electrophysiological characteristics of the resulting current (Lorenz et al. 1996). Furthermore, like the voltage-inactivated current in embryos, ClC1 is not blocked by DIDS (Steinmeyer et al. 1995, Jentsch 2008) but is inhibited by 9-AC, which has been shown to decrease expansion of rat blastocysts (Brison \& Leese 1993) and mouse blastocysts (this study). Taken together, these data suggest that the voltage-inactivated $\mathrm{Cl}^{-}$current is composed of $\mathrm{ClC} 1$ and expressed in the mouse trophoblast lineage where it plays a role in blastocyst expansion.

In summary, all members of the voltage-gated $\mathrm{Cl}^{-}$channel gene family are expressed at the RNA level in the preimplantation mouse conceptus. Two types of voltage-gated $\mathrm{ClC}$ activities were detected using whole-cell voltage clamp methods, one of which was outwardly rectifying, inhibited by DIDS and present at all stages of development from oocyte to blastocyst and may be composed of CLCN3 channel proteins. A second $\mathrm{Cl}^{-}$conductance, which was inactivated by membrane depolarization, was only expressed in the trophoblast lineage. Inhibition of both these conductances was required to prevent blastocyst expansion. 


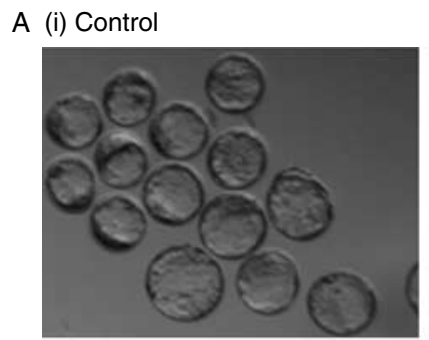

(ii) $100 \mu \mathrm{M}$ DIDS

(iii) $1 \mathrm{mM} 9-\mathrm{AC}$
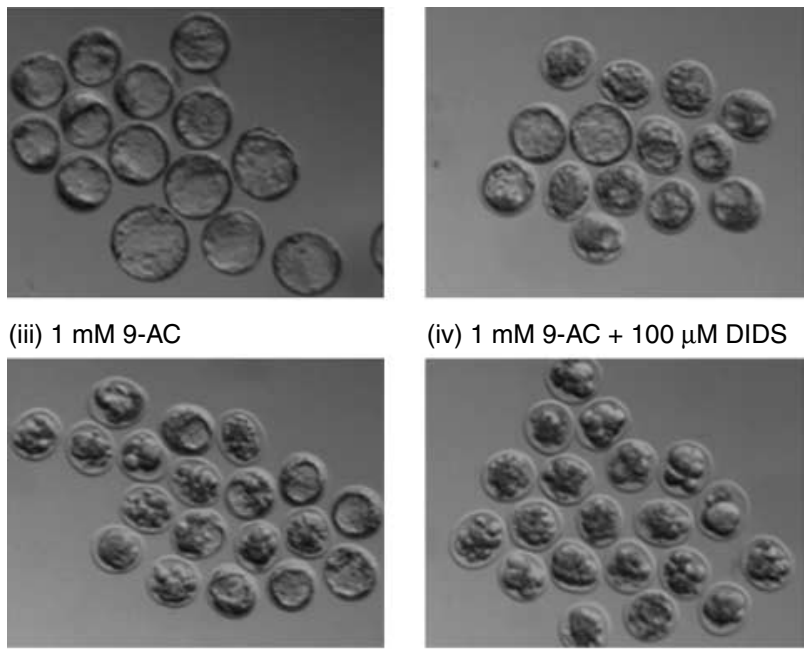

(iv) $1 \mathrm{mM} 9-\mathrm{AC}+100 \mu \mathrm{M}$ DIDS

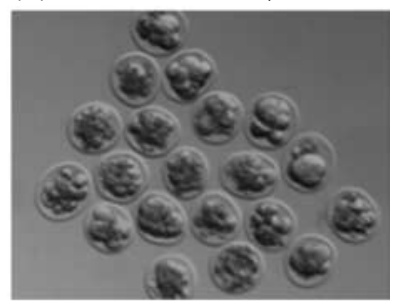

$\mathrm{B}$

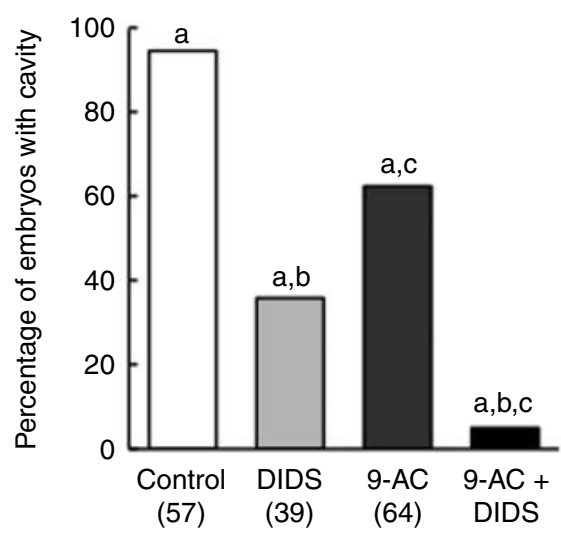

(40)

Figure $8 \mathrm{Effect}$ of $\mathrm{Cl}^{-}$channel inhibitors on blastocoel cavity formation. (A) Representative photomicrographs of embryos following 40-48 h of culture in (i) control medium (containing 0.2\% DMSO), (ii) $100 \mu \mathrm{M}$ DIDS, (iii) $1 \mathrm{mM}$ 9-AC, or (iv) $100 \mu \mathrm{M}$ DIDS + $1 \mathrm{mM}$ 9-AC. (B) Proportion of embryos that formed an expanded, fluid-filled cavity in control medium (containing 0.2\% DMSO), $100 \mu \mathrm{M}$ DIDS, 1 mM 9-AC, or $100 \mu \mathrm{M}$ DIDS + $1 \mathrm{mM}$ 9-AC. The numbers of embryos in each treatment are shown in brackets and were from three to six separate culture experiments. Treatments with the same letter are significantly different $(P<0.01)$.

\section{Materials and Methods}

\section{Collection and culture of oocytes and conceptuses}

Quackenbush strain (QS) female mice (3-5 weeks old) on a fixed $12 \mathrm{~h}$ light:12 h darkness cycle were superovulated by i.p. injections of 10 intrauterine pregnant mares' serum gonadotropin (Intervet, Bendigo East, Victoria, Australia), followed $\sim 48 \mathrm{~h}$ later by 10 intrauterine human chorionic gonadotropin (hCG; Intervet). Some of the female mice were then paired overnight with male QS mice ( $>12$ weeks old) and mating ascertained by the presence of a vaginal plug. The use of animals was in accordance with the Australian Code of Practice for the Care and Use of Animals for Scientific Purposes and was approved by the Institutional Animal Care and Ethics
Committee. Unfertilized oocytes, 1-cell zygotes, 2-, 4-, and 8-cell stages, morula, and blastocysts were obtained from female mice killed by cervical dislocation at 12.5-13, 18-24, 39-44, 47-48, 69-72, 81-83, and 93-95 h post-hCG injection respectively. Unfertilized oocytes and zygotes were teased or flushed from the oviducts into M2 medium (Fulton \& Whittingham 1978) containing $4 \mathrm{mg} / \mathrm{ml}$ BSA (M2+ BSA). Cumulus cells were removed by brief exposure to hyaluronidase $(0.2 \mathrm{mg} / \mathrm{ml}$; Type II, Sigma) and oocytes stored in $\mathrm{M} 2+$ BSA until used. Zygotes were cultured in medium M16 (Chatot et al. 1989) or KSOM (Erbach et al. 1994) containing $4 \mathrm{mg} / \mathrm{ml}$ BSA under liquid paraffin oil (Sigma) in $5 \% \mathrm{CO}_{2}$ at $37^{\circ} \mathrm{C}$. The media contained no phenol red or antibiotics at any stage. The 2-, 4-, and 8-cell conceptuses and morulae were flushed from the oviducts and blastocysts from the uteri and cultured until use. The zona pellucida was removed by brief exposure to acid Tyrode's solution, and embryos were allowed to recover for 30 min before use.

In addition to the use of whole concept, chloride current activities in later stage embryogenic cells were also examined in isolated individual cells or small cell clusters. These were prepared from the conceptus according to well-established and validated procedures (for details, see Johnson \& Ziomek (1982, 1983)). Briefly, 8- to 16-cell stages were rinsed through $\mathrm{Ca}^{2+}$ free $M 2$ medium, after which they were incubated in the same medium for $10 \mathrm{~min}$ at $37^{\circ} \mathrm{C}$. The cells were then disaggregated using a fine flame-polished micropipette. Individual 1/8, 1/16, and 2/16 blastomeres were then cultured under oil until their use either as single cells, pairs, or, when division had occurred, as small cell clusters (2-4/16) or 'mini-blastocysts' (2-8/32 and $4-8 / 64)$. The smaller cells isolated from 16-cell concepti were apolar, inner cells (Ziomek et al. 1982).

ICMs were isolated by immunosurgery (Solter \& Knowles 1975). Fully expanded zona-intact blastocysts were incubated in $\mathrm{M} 2+\mathrm{BSA}$ containing heat-inactivated rabbit anti-mouse spleen cell serum (kindly provided by Prof. Peter Kaye, University of Queensland) at $37^{\circ} \mathrm{C}$ for $10 \mathrm{~min}$. Blastocysts were then washed in $\mathrm{M} 2+\mathrm{BSA}$ and incubated for $20 \mathrm{~min}$ in $\mathrm{M} 2+\mathrm{BSA}$ containing guinea pig complement (ICN Biochemicals, Irvine, CA, USA) at $37^{\circ} \mathrm{C}$. The ICMs were separated from the dead trophoblasts by aspiration through a narrow bore pipette. The ICM was then washed and incubated in M16+ BSA under oil in $5 \% \mathrm{CO}_{2}$ at $37{ }^{\circ} \mathrm{C}$ for $30 \mathrm{~min}$ in order to ensure absence of contaminating fluid accumulating cells. TE cells were isolated from blastocysts by embryo bisection, performed in $\mathrm{M} 2+\mathrm{BSA}$ at $37^{\circ} \mathrm{C}$ on an agar-coated Petri dish ( $1 \%$ agar in $0.9 \% \mathrm{NaCl}$; Day et al. 1998). The cutting was accomplished by pressing a fine glass pipette down onto individual zona-free blastocysts so that the ICM was pushed to one side. The two embryo fragments were separated by gentle pipetting, thereby producing a fragment that contained the ICM, surrounded by trophoblasts, which was discarded, and a fragment composed of trophoblasts only, which was used for RT-PCR.

The effect of $\mathrm{Cl}^{-}$channel inhibitors on blastocyst expansion was examined by culturing morulae in groups of 15-20 in $20 \mu \mathrm{l}$ KSOM containing either 0.2\% DMSO (control), $1 \mathrm{mM}$ 9-AC, $100 \mu \mathrm{M}$ DIDS, or $1 \mathrm{mM}$ 9-AC and $100 \mu \mathrm{M}$ DIDS. Embryos were analyzed visually for the presence of an expanded, fluidfilled blastocoel after 40-48 h in culture. Embryos were imaged 
using a Leica DFC450C digital camera attached to a stereo microscope (Leica MZ FLIII).

\section{Patch-clamping}

Standard whole-cell patch-clamp techniques were used to study $\mathrm{Cl}^{-}$currents as described previously (Day et al. 1998) using a List EPC-7 patch-clamp amplifier (List, Darmstadt, Germany). All patch-clamp experiments were performed at room temperature. Patch-clamp pipettes were manufactured from borosilicate microhematocrit tubes (Modulohm, Herlev, Denmark) and had a resistance of 2-5 $\mathrm{M} \Omega$ when filled with $\mathrm{N}$-methyl-D-glucamine (NMDG)-glutamate pipette solution, which had the following composition (in mM): NMDG-glutamate (130), $\mathrm{MgCl}_{2}$ (1), H-HEPES (10), glucose (10), H-EGTA (0.5), $\mathrm{H}$-EDTA (0.01), $\mathrm{pH}$ adjusted to 7.2 with $\mathrm{HCl}(\sim 23 \mathrm{mM})$, with an osmolality of $290-300 \mathrm{mOsm} / \mathrm{kg}$. Use of this pipette solution eliminated currents due to outward $\mathrm{K}^{+}$movement through $\mathrm{K}^{+}$channels and therefore enabled the analysis of $\mathrm{Cl}^{-}$movement into the cell in isolation. The membrane potential was held at $0 \mathrm{mV}$ and square-wave voltage pulses of $1 \mathrm{~s}$ duration between -120 and $+120 \mathrm{mV}$ were then applied. Currents were low-pass filtered, sampled, and digitized at $0.2 \mathrm{kHz}$ with a MacLab-4 data acquisition interface (AD Instruments, Sydney, NSW, Australia) attached to a Macintosh computer. By convention, outward current is the movement of positive charge out of the pipette (i.e. out of the cell in wholecell recording mode) or movement of negative charge into the pipette/cell. An agar bridge (1\% (w/v) agar in $150 \mathrm{mM} \mathrm{KCl})$ was used to connect the reference electrode to the bath solution when necessary. Liquid junction potentials between the bath and pipette electrodes were calculated using the Henderson equation (Barry \& Lynch 1991) and were used to correct holding potentials. Currents are expressed relative to the cell capacitance $(\mathrm{pA} / \mathrm{pF})$ calculated from a voltage pulse to $-10 \mathrm{mV}$ in order to adjust for differences in cell size between each embryonic stage. Current-voltage relationships
(I-V curves) were plotted and the chord conductance was calculated between $+100 \mathrm{mV}$ and the voltage at which current is zero (i.e. the reversal potential). The chord conductance is the slope of the line on the $\mathrm{I}-\mathrm{V}$ curve between the current at $+100 \mathrm{mV}$ and the reversal potential and is used when the I-V curve is not linear. The chord conductance eliminates the effect of any changes in reversal potential on the calculation of conductance. The $\mathrm{Cl}^{-}$sensitive conductance was calculated by subtracting the conductance remaining after removal of extracellular $\mathrm{Cl}^{-}$from the conductance obtained in the presence of extracellular $\mathrm{Cl}^{-}$. Similarly, the DIDSsensitive conductance was calculated by subtracting the conductance obtained in the presence of DIDS from the conductance in the absence of DIDS, with both these recordings made in the presence of extracellular $\mathrm{Cl}^{-}$.

The standard bathing solution used was protein-free M2 medium (Fulton \& Whittingham 1978) containing (in mM) $\mathrm{NaCl}$ (140), $\mathrm{MgCl}_{2}$ (1.19), $\mathrm{CaCl}_{2}$ (1.71), H-HEPES (10), and glucose (5.56). The chloride-free solution contained Na-glutamate (140), $\mathrm{MgCl}_{2}$ (1.19), $\mathrm{CaCl}_{2}$ (1.71), H-HEPES (10), and glucose (5.56). The osmolality of all solutions was 290-300 mOsm/kg and the $\mathrm{pH}$ was adjusted to 7.40.

\section{RT-PCR of embryogenic mRNA}

Freshly recovered conceptuses were rinsed and sorted into homogeneously staged cohorts of 50. Each cohort was transferred to a PCR tube in minimal volume $(\sim 0.1 \mu \mathrm{l})$ of medium and the tube was immediately immersed in liquid nitrogen. Tubes were stored at $-80{ }^{\circ} \mathrm{C}$ until used in RT-PCR. Alternatively, embryos were collected into $100 \mu$ l Tri-reagent (Sigma), $50 \mu \mathrm{g} / \mathrm{ml}$ glycogen was added to aid in forming the RNA pellet. Tubes were stored at $4{ }^{\circ} \mathrm{C}$ until used in RNA extraction. RNA extraction was carried out using Tri-reagent as per manufacturer's instructions (Sigma).

A RT mix containing $1 \mathrm{mM}$ dNTPs (Invitrogen), $20 \mathrm{ng} / \mathrm{ml}$ random hexamers (Invitrogen), $10 \mathrm{mM}$ dithiothreitol

Table 2 Primers used for RT-PCR amplification of mouse Clcn transcripts.

\begin{tabular}{|c|c|c|c|c|c|}
\hline $\begin{array}{l}\text { Gene (accession } \\
\text { number) }\end{array}$ & Direction & Sequence $\left(5^{\prime}-3^{\prime}\right)$ & $\begin{array}{l}\text { Location } \\
\text { (nucleotide) }\end{array}$ & $\begin{array}{c}\text { Annealing } \\
\text { temperature }\left({ }^{\circ} \mathrm{C}\right)\end{array}$ & $\begin{array}{l}\text { Amplicon } \\
\text { size (bp) }\end{array}$ \\
\hline Clcn1 $^{\mathrm{a}}$ (NM_013491) & $\begin{array}{l}\text { S } \\
\text { AS }\end{array}$ & $\begin{array}{l}\text { CTGCATTTGGAAGGCTGGTAGGAG } \\
\text { AATGACGGCTGTGGAGACTGTGTG }\end{array}$ & $1557-1717$ & 62 & 161 \\
\hline Clcn2 (NM_009900) & $\begin{array}{l}\text { S } \\
\text { AS }\end{array}$ & $\begin{array}{l}\text { TGAGTCCATGATCCTACTG } \\
\text { CCTGCTGACTCCATGTTG }\end{array}$ & $2519-2827$ & 55 & 309 \\
\hline Clcn3 (NM_007711) & $\begin{array}{l}\mathrm{S} \\
\mathrm{AS}\end{array}$ & $\begin{array}{l}\text { CCTCTTTCCAAAGTATAGCAC } \\
\text { CTGGCATTCATGTCATTTC }\end{array}$ & $1270-1818$ & 55 & 549 \\
\hline Clcn4-2 (NM_011334) & $\begin{array}{l}\mathrm{S} \\
\mathrm{AS}\end{array}$ & $\begin{array}{l}\text { GAGGACTTCCACACCATA } \\
\text { TGCAAACAGCAACGCCCATA }\end{array}$ & 509-919 & 55 & 411 \\
\hline Clcn5 (NM_016691) & $\begin{array}{l}\mathrm{S} \\
\mathrm{AS}\end{array}$ & $\begin{array}{l}\text { GGAACATCTTGTGCCACTG } \\
\text { TGTGTTGAAGTGGTTCTC }\end{array}$ & 895-1457 & 55 & 563 \\
\hline Clcn6 (NM_011929) & $\begin{array}{l}\text { S } \\
\text { AS }\end{array}$ & $\begin{array}{l}\text { TCTTCCACGAGTCAAACC } \\
\text { TCATCCTTACAACCCCAC }\end{array}$ & $1207-1612$ & 55 & 406 \\
\hline Clcn7 (NM_011930) & $\begin{array}{l}\mathrm{S} \\
\mathrm{AS}\end{array}$ & $\begin{array}{l}\text { CGTGAGAATGACCCTTAGCC } \\
\text { GTCTCСТACATCСТCСАССАС }\end{array}$ & 1754-2084 & 60 & 331 \\
\hline $\begin{array}{l}\text { Clcnka and } b \\
\text { (NM_024412/ } \\
\text { NM_019701) }\end{array}$ & $\begin{array}{l}\mathrm{S} \\
\mathrm{AS}\end{array}$ & $\begin{array}{l}\text { CATCACCTCCATCTACAAGACC } \\
\text { AGAATCAGCATCCAGAAC }\end{array}$ & $\begin{array}{l}841-1299(\mathrm{k} 1) \\
834-1292(\mathrm{k} 2)\end{array}$ & 55 & 459 \\
\hline B-actin (NM_007393) & $\begin{array}{l}\mathrm{S} \\
\mathrm{AS}\end{array}$ & $\begin{array}{l}\text { CATGTACGTAGCCATCCAG } \\
\text { AAACGCAGCTCAGTAACAG }\end{array}$ & $472-1231$ & 52 & 760 \\
\hline
\end{tabular}

$\mathrm{S}$, sense primer; $\mathrm{AS}$, antisense primer.

a'Yamamoto-Mizuma et al. (2004). 
(Invitrogen), $0.1 \mathrm{mg} / \mathrm{ml}$ BSA (Amersham Pharmacia Biotech), and 16 units RNasin (Promega) was prepared and the volume adjusted to $8.9 \mu \mathrm{l}$ with double-distilled water (Baxter, Toongabbie, NSW, Australia). Before addition of reverse transcriptase, the reaction mix was added to the PCR tube containing frozen conceptuses and heated to $65^{\circ} \mathrm{C}$ for $1 \mathrm{~min}$. Two hundred units of reverse transcriptase (superscript II, Invitrogen) was then added and the RNA was reverse transcribed at $37^{\circ} \mathrm{C}$ for $60 \mathrm{~min}$. The $\mathrm{RT}$ reaction was terminated by heating to $95^{\circ} \mathrm{C}$ for $10 \mathrm{~min}$. The resulting cDNA samples were stored at $-20{ }^{\circ} \mathrm{C}$ until use.

PCR primers were designed using GCG (ANGIS) based on cDNA sequence data available in GenBank. The primers used and the expected PCR product sizes are shown in Table 2. A PCR mix containing PCR buffer (Promega), $25 \mu \mathrm{M} \mathrm{MgCl}_{2}$ (Promega), 2.5 units Taq DNA polymerase (Promega), and $0.5 \mu \mathrm{M}$ of $5^{\prime}$ and $3^{\prime}$ gene-specific primers was prepared and made up to $40 \mu \mathrm{l}$ with double-distilled water. This reaction mix was then added to $10 \mu \mathrm{l}$ cDNA. The PCR was run on a GeneAmp PCR system 2400 (PE Applied Biosystems) at $94{ }^{\circ} \mathrm{C}$ for $1 \mathrm{~min}$ followed by $30-40$ cycles of amplification $\left(94^{\circ} \mathrm{C}\right.$ for $30 \mathrm{~s}, 30 \mathrm{~s}$ at annealing temperatures of $52-60{ }^{\circ} \mathrm{C}$ depending on the primer set used (Table 2), and $68{ }^{\circ} \mathrm{C}$ for $4 \mathrm{~min}$ ) and a final extension at $72{ }^{\circ} \mathrm{C}$ for $7 \mathrm{~min}$.

PCR products were run on a $2 \%(w / v)$ agarose gel, the correct sized bands were cut from the agarose gel, and the DNA was purified using a gel extraction kit according to the manufacturer's instructions (Qiagen). PCR products were cloned into the pGEM-Teasy vector and sequenced by the Australian Genome Research Facility (AGRF).

\section{Immunostaining}

Zona-free embryos were fixed by incubation in $4 \%(\mathrm{w} / \mathrm{v})$ paraformaldehyde in PBS containing $1 \mathrm{mg} / \mathrm{ml}$ polyvinyl alcohol (PBS/PVA) for $30 \mathrm{~min}$. Embryos were then permeabilized by incubation in the same solution containing $0.3 \%$ Triton X-100 for $30 \mathrm{~min}$. The embryos were then washed in PBS+PVA and then incubated in PBS/PVA containing $0.7 \%(\mathrm{w} / \mathrm{v}) \mathrm{BSA}(\mathrm{PBS} / \mathrm{PVA} / \mathrm{BSA})$ for $30 \mathrm{~min}$ at room temperature before incubation in $8 \mu \mathrm{g} / \mathrm{ml}$ anti-CLCN3 antibody (Alomone Labs, Jerusalem, Israel) in PBS/PVA/BSA for $2 \mathrm{~h}$ at room temperature. Embryos were then washed three times in PBS/PVA/BSA and incubated in $10 \mu \mathrm{g} / \mathrm{ml}$ Alexa Fluor 488 goat anti-rabbit IgG (Molecular Probes, Eugene, OR, USA) in PBS/PVA/BSA for $1 \mathrm{~h}$. After washing three times in PBS/PVA/BSA, the embryos were mounted in vectashield containing $1.5 \mu \mathrm{g} / \mathrm{ml}$ 4'6-diamidino-2-phenylindole (DAPI) (Vector Laboratories, Burlingame, CA, USA) on a slide. All procedures were performed at room temperature. A confocal microscope (TCS NT, Leica) was used to observe the stained embryos (Bosch Institute, Advanced Microscopy Facility, University of Sydney). Images were captured using Leica confocal Assistant Software (version 4.02).

\section{Statistical analysis}

These data are expressed as the mean \pm s.E.M. with the number of experiments $(n)$ in parentheses. Normality was tested using a
Shapiro-Wilk test and data were compared using ANOVA followed by Tukey-Kramer post hoc test or paired Student's t-test (StatPlus, AnalystSoft, www.analystsoft.com) when appropriate. $\chi^{2}$ Test was used to compare proportions. $P$ values $<0.05$ were considered statistically significant.

\section{Chemicals}

Culture solutions were made from cell culture grade reagents obtained from Sigma. DIDS and 9-AC (both from Sigma) were prepared as $100 \mathrm{mM}$ and $1 \mathrm{M}$ stock solutions in DMSO on the day of use respectively.

\section{Declaration of interest}

The authors declare that there is no conflict of interest that could be perceived as prejudicing the impartiality of the research reported.

\section{Funding}

This project was supported by grants from the NHMRC Australia and ARC to M L Day and D I Cook and by a travel grant from the Royal Society and a Wellcome Collaborative Grant to $\mathrm{M} \mathrm{H}$ Johnson.

\section{Acknowledgements}

The authors thank Peter Kaye (University of Queensland) for the gift of the rabbit anti-mouse antiserum and Louise Cole (Bosch Institute Advanced Microscopy Facility, University of Sydney) for assistance with confocal microscopy.

\section{References}

Barry PH \& Lynch JW 1991 Liquid junction potentials and small cell effects in patch-clamp analysis. Journal of Membrane Biology 121 101-117. (doi:10.1007/BF01870526)

Biggers JD 1998 Reflections on the culture of the preimplantation embryo. International Journal of Developmental Biology 42 879-884.

Biggers JD 2002 Thoughts on embryo culture conditions. Reproductive Biomedicine Online 4 (Suppl 1) 30-38. (doi:10.1016/S1472-6483(12) 60009-1)

Biggers JD, Borland RM \& Lechene CP 1978 Ouabain-sensitive fluid accumulation and ion transport by rabbit blastocysts. Journal of Physiology 280 319-330.

Block ML \& Moody WJ 1990 A voltage-dependent chloride current linked to the cell cycle in ascidian embryos. Science 247 1090-1092. (doi:10.1126/science.2309122)

Brison DR \& Leese HJ 1993 Role of chloride transport in the development of the rat blastocyst. Biology of Reproduction 48 692-702. (doi:10.1095/ biolreprod48.3.692)

Chatot CL, Ziomek CA, Bavister BD, Lewis JL \& Torres I 1989 An improved culture medium supports development of random-bred 1-cell mouse embryos in vitro. Journal of Reproduction and Fertility 86 679-688. (doi:10.1530/jrf.0.0860679)

Cuddapah VA \& Sontheimer H 2010 Molecular interaction and functional regulation of $\mathrm{ClC}-3$ by $\mathrm{Ca}^{2+} /$ calmodulin-dependent protein kinase II (CaMKII) in human malignant glioma. Journal of Biological Chemistry 285 11188-11196. (doi:10.1074/jbc.M109.097675)

Day ML, Pickering SJ, Johnson MH \& Cook DI 1993 Cell-cycle control of a large-conductance $\mathrm{K}^{+}$channel in mouse early embryos. Nature 365 560-562. (doi:10.1038/365560a0) 
Day ML, Johnson MH \& Cook DI 1998 A cytoplasmic cell cycle controls the activity of a $\mathrm{K}^{+}$channel in pre-implantation mouse embryos. EMBO Journal 17 1952-1960. (doi:10.1093/emboj/17.7.1952)

Day ML, McGuinness OM, Berridge MJ \& Johnson MH 2000 Regulation of fertilization-induced $\mathrm{Ca}^{2+}$ spiking in the mouse zygote. Cell Calcium $\mathbf{2 8}$ 47-54. (doi:10.1054/ceca.2000.0128)

DiZio SM \& Tasca RJ 1977 Sodium-dependent amino acid transport in preimplantation mouse embryos. III. $\mathrm{Na}^{+}-\mathrm{K}^{+}$-ATPase-linked mechanism in blastocysts. Developmental Biology 59 198-205. (doi:10.1016/ 0012-1606(77)90254-8)

Duan D, Winter C, Cowley S, Hume JR \& Horowitz B 1997 Molecular identification of a volume-regulated chloride channel. Nature $\mathbf{3 9 0}$ 417-421. (doi:10.1038/37151)

Erbach GT, Lawitts JA, Papaioannou VE \& Biggers JD 1994 Differential growth of the mouse preimplantation embryo in chemically defined media. Biology of Reproduction 50 1027-1033. (doi:10.1095/biolreprod50.5.1027)

Fulton BP \& Whittingham DG 1978 Activation of mammalian oocytes by intracellular injection of calcium. Nature 273 149-151. (doi:10.1038/ 273149a0)

Gibb CA, Poronnik P, Day ML \& Cook DI 1997 Control of cytosolic pH in two-cell mouse embryos: roles of $\mathrm{H}^{+}$-lactate cotransport and $\mathrm{Na}{ }^{+} / \mathrm{H}^{+}$ exchange. American Journal of Physiology. Cell Physiology 273 C404-C419.

Guan Y-Y, Wang G-L \& Zhou J-G 2006 The $\mathrm{ClC}-3 \mathrm{Cl}^{-}$channel in cell volume regulation, proliferation and apoptosis in vascular smooth muscle cells. Trends in Pharmacological Sciences 27 290-296. (doi:10.1016/j.tips.2006.04.008)

Habela CW, Olsen ML \& Sontheimer H 2008 ClC3 is a critical regulator of the cell cycle in normal and malignant glial cells. Journal of Neuroscience 28 9205-9217. (doi:10.1523/JNEUROSCI.1897-08.2008)

Harding EA, Day ML, Gibb CA, Johnson MH \& Cook DI 1999 The activity of the $\mathrm{H}^{+}$-monocarboxylate cotransporter during pre-implantation development in the mouse. Pflügers Archiv: European Journal of Physiology 438 397-404. (doi:10.1007/s004240050927)

Harding EA, Gibb CA, Johnson MH, Cook DI \& Day ML 2002 Developmental changes in the management of acid loads during preimplantation mouse development. Biology of Reproduction 67 1419-1429. (doi:10.1095/ biolreprod.102.005637)

Jentsch TJ 2008 CLC chloride channels and transporters: from genes to protein structure, pathology and physiology. Critical Reviews in Biochemistry and Molecular Biology 43 3-36. (doi:10.1080/1040 9230701829110)

Johnson MH 1986 Manipulation of early mammalian development: what does it tell us about cell lineages? Developmental Biology 4 279-296.

Johnson MH 2009 From mouse egg to mouse embryo: polarities, axes, and tissues. Annual Review of Cell and Developmental Biology 25 483-512. (doi:10.1146/annurev.cellbio.042308.113348)

Johnson MH \& Ziomek CA 1982 Cell subpopulations in the late morula and early blastocyst of the mouse. Developmental Biology 91 431-439. (doi:10.1016/0012-1606(82)90049-5)

Johnson MH \& Ziomek CA 1983 Cell interactions influence the fate of mouse blastomeres undergoing the transition from the 16- to the 32-cell stage. Developmental Biology 95 211-218. (doi:10.1016/0012-1606 (83)90019-2)

Kolajova M \& Baltz JM 1999 Volume-regulated anion and organic osmolyte channels in mouse zygotes. Biology of Reproduction 60 964-972. (doi:10.1095/biolreprod60.4.964)

Kolajova M, Hammer MA, Collins JL \& Baltz JM 2001 Developmentally regulated cell cycle dependence of swelling-activated anion channel activity in the mouse embryo. Development 128 3427-3434.

Lane M, Baltz JM \& Bavister BD 1999a Bicarbonate/chloride exchange regulates intracellular $\mathrm{pH}$ of embryos but not oocytes of the hamster. Biology of Reproduction 61 452-457. (doi:10.1095/biolreprod61.2.452

Lane M, Baltz JM \& Bavister BD $1999 b \mathrm{Na}+/ \mathrm{H}^{+}$antiporter activity in hamster embryos is activated during fertilization. Developmental Biology 208 244-252. (doi:10.1006/dbio.1999.9198)

Leese HJ 1995 Metabolic control during preimplantation mammalian development. Human Reproduction Update 1 63-72. (doi:10.1093/ humupd/1.1.63)
Leese HJ, Sturmey RG, Baumann CG \& McEvoy TG 2007 Embryo viability and metabolism: obeying the quiet rules. Human Reproduction 22 3047-3050. (doi:10.1093/humrep/dem253)

Li Y, Chandrakanthan V, Day ML \& O'Neill C 2007 Direct evidence for the action of phosphatidylinositol $(3,4,5)$-trisphosphate-mediated signal transduction in the 2-cell mouse embryo. Biology of Reproduction 77 813-821. (doi:10.1095/biolreprod.107.060129)

Li Y, O'Neill C \& Day ML 2009 Activation of a chloride channel by a trophic ligand is required for development of the mouse preimplantation embryo in vitro. Biology of Reproduction 81 759-767. (doi:10.1095/biolreprod. 108.074567)

Lorenz C, Pusch M \& Jentsch TJ 1996 Heteromultimeric CLC chloride channels with novel properties. PNAS 93 13362-13366. (doi:10.1073/ pnas.93.23.13362)

Manejwala FM, Cragoe EJ \& Schultz RM 1989 Blastocoel expansion in the preimplantation mouse embryo: role of extracellular sodium and chloride and possible apical routes of their entry. Developmental Biology 133 210-220. (doi:10.1016/0012-1606(89)90312-6)

McGuinness OM, Moreton RB, Johnson MH \& Berridge MJ 1996 A direct measurement of increased divalent cation influx in fertilised mouse oocytes. Development 122 2199-2206.

Mitchell J, Wang X, Zhang G, Gentzsch M, Nelson DJ \& Shears SB 2008 An expanded biological repertoire for $\operatorname{Ins}(3,4,5,6) \mathrm{P} 4$ through its modulation of ClC-3 function. Current Biology 18 1600-1605. (doi:10.1016/ j.cub.2008.08.073)

O'Neill C 2008 The potential roles for embryotrophic ligands in preimplantation embryo development. Human Reproduction Update 14 275-288. (doi:10.1093/humupd/dmn002)

Phillips KP \& Baltz JM 1999 Intracellular pH regulation by $\mathrm{HCO} 3-/ \mathrm{Cl}-$ exchange is activated during early mouse zygote development. Developmental Biology 208 392-405. (doi:10.1006/dbio.1999.9199)

Picollo A, Liantonio A, Didonna MP, Elia L, Camerino DC \& Pusch M 2004 Molecular determinants of differential pore blocking of kidney CLC-K chloride channels. EMBO Reports 5 584-589. (doi:10.1038/sj.embor.7400169)

Rutledge E, Bianchi L, Christensen M, Boehmer C, Morrison R, Broslat A, Beld AM, George AL, Greenstein D \& Strange K 2001 CLH-3, a ClC-2 anion channel ortholog activated during meiotic maturation in $C$. elegans oocytes. Current Biology 11 161-170. (doi:10.1016/S09609822(01)00051-3)

Séguin DG \& Baltz JM 1997 Cell volume regulation by the mouse zygote: mechanism of recovery from a volume increase. American Journal of Physiology 272 C1854-C1861.

Solter D \& Knowles BB 1975 Immunosurgery of mouse blastocyst. PNAS 72 5099-5102. (doi:10.1073/pnas.72.12.5099)

Sonoda M, Okamoto F, Kajiya H, Inoue Y, Honjo K, Sumii Y, Kawarabayashi T \& Okabe K 2003 Amino acid-permeable anion channels in early mouse embryos and their possible effects on cleavage. Biology of Reproduction 68 947-953. (doi:10.1095/biolreprod.102.007088)

Steinmeyer K, Schwappach B, Bens M, Vandewalle A \& Jentsch TJ 1995 Cloning and functional expression of rat CLC-5, a chloride channel related to kidney disease. Journal of Biological Chemistry 270 31172-31177. (doi:10.1074/jbc.270.52.31172)

Strange K, Emma F \& Jackson PS 1996 Cellular and molecular physiology of volume-sensitive anion channels. American Journal of Physiology 270 C711-C730.

Tang Y-B, Liu Y-J, Zhou J-G, Wang G-L, Qiu Q-Y \& Guan Y-Y 2008 Silence of $\mathrm{ClC}-3$ chloride channel inhibits cell proliferation and the cell cycle via G/S phase arrest in rat basilar arterial smooth muscle cells. Cell Proliferation 41 775-785. (doi:10.1111/j.1365-2184.2008.00551.x)

Thiemann A, Gründer S, Pusch M \& Jentsch TJ 1992 A chloride channel widely expressed in epithelial and non-epithelial cells. Nature 356 57-60. (doi:10.1038/356057a0)

Thompson JGB, Mitchell M \& Kind KL 2007 Embryo culture and long-term consequences. Reproduction, Fertility, and Development 19 43-52. (doi:10.1071/RD06129)

Watson AJ \& Kidder GM 1988 Immunofluorescence assessment of the timing of appearance and cellular distribution of $\mathrm{Na} / \mathrm{K}$-ATPase during mouse embryogenesis. Developmental Biology 126 80-90. (doi:10.1016/0012-1606(88)90241-2)

Wiley LM 1984 Cavitation in the mouse preimplantation embryo: $\mathrm{Na} / \mathrm{K}-\mathrm{ATPa}$ e and the origin of nascent blastocoele fluid. Developmental Biology 105 330-342. (doi:10.1016/0012-1606(84)90290-2) 
Wiley LM, Kidder GM \& Watson AJ 1990 Cell polarity and development of the first epithelium. BioEssays: News and Reviews in Molecular, Cellular and Developmental Biology 12 67-73. (doi:10.1002/bies. 950120204)

Wiley LM, Lever JE, Pape C \& Kidder GM 1991 Antibodies to a renal $\mathrm{Na}^{+} /$glucose cotransport system localize to the apical plasma membrane domain of polar mouse embryo blastomeres. Developmental Biology 143 149-161. (doi:10.1016/0012-1606(91)90062-8)

Yamamoto-Mizuma S, Wang G-X, Liu LL, Schegg K, Hatton WJ, Duan D, Horowitz TLB, Lamb FS \& Hume JR 2004 Altered properties of volumesensitive osmolyte and anion channels (VSOACs) and membrane protein expression in cardiac and smooth muscle myocytes from $\mathrm{Clcn} 3-/-$ mice. Journal of Physiology 557 439-456. (doi:10.1113/jphysiol.2003. 059261)

Yang L, Ye D, Ye W, Jiao C, Zhu L, Mao J, Jacob TJC, Wang L \& Chen L 2011 ClC-3 is a main component of background chloride channels activated under isotonic conditions by autocrine ATP in nasopharyngeal carcinoma cells. Journal of Cellular Physiology 226 2516-2526. (doi:10.1002/jcp.22596)
Zhao Y, Doroshenko PA, Alper SL \& Baltz JM 1997 Routes of Cl - transport across the trophectoderm of the mouse blastocyst. Developmental Biology 189 148-160. (doi:10.1006/dbio.1997.8651)

Zhu L, Yang H, Zuo W, Yang L, Zhang H, Ye W, Mao J, Chen L \& Wang L 2012 Differential expression and roles of volume-activated chloride channels in control of growth of normal and cancerous nasopharyngeal epithelial cells. Biochemical Pharmacology 83 324-334. (doi:10.1016/j. bcp.2011.11.007)

Ziomek CA, Johnson MH \& Handyside AH 1982 The developmental potential of mouse 16-cell blastomeres. Journal of Experimental Zoology 221 345-355. (doi:10.1002/jez.1402210310)

Received 18 February 2012

First decision 12 April 2012

Revised manuscript received 13 September 2012

Accepted 31 October 2012 